\title{
Synthesis and Photochemical Reaction of Poly(ester)s Containing Donor-Acceptor Type Norbornadiene Residues in the Both Main and Side Chains
}

\author{
Yoshitomo ONO, ${ }^{1}$ Naoyuki KaWASHIMA, ${ }^{1}$ Hiroto Kudo, ${ }^{1}$ \\ Takabumi NAGAI, ${ }^{2}$ and Tadatomi NISHIKUBO ${ }^{1, \dagger}$ \\ ${ }^{1}$ Department of Applied Chemistry, Faculty of Engineering, Kanagawa University, \\ 3-27-1, Rokkakubashi, Kanagawa-ku, Yokohama 221-8686, Japan \\ ${ }^{2}$ Daikin Environmental Laboratory, Ltd., 3-Banchi, Miyukigaoka, Tsukuba 305-0845, Japan
}

(Received September 15, 2004; Accepted January 5, 2005; Published April 15, 2005)

\begin{abstract}
The synthesis and photochemical valence isomerization of polymers containing donor-acceptor type norbornadiene (D-A NBD) residues in both main and side chains, by the polyaddition of 5-(4-methoxyphenyl)1,4,6,7,7-pentamethyl-2,5-norbornadiene-2,3-dicarboxylic acid diglycidyl ester (D-A NDGE) with terephthaloyl chloride follows by substitution reactions of the resulting polymer with potassium 5-(4-methoxyphenyl)-1,4,6,7,7-pentamethyl-3-methylester-2,5-NBD-2-carboxylate, potassium 5-(4-methoxyphenyl)-1,4,6,7,7-pentamethyl-3-( $N, N$-dipropylcarbamoyl)-2,5-NBD-2-carboxylate, and potassium 5-(4-methoxyphenyl)-1,4,6,7,7-pentamethyl-3-( $N$-methyl- $N$ phenylcarbamoyl)-2,5-NBD-2-carboxylate, respectively. The photochemical valence isomerization of the synthesized poly(ester)s (P-1-P-4, and P-5a-c) was examined in tetrahydrofuran solution or in the film state upon irradiation with a 500-W xenon lamp, and it was found that each photochemical reaction proceeded very smoothly. It was also observed that the rate of the photochemical reaction of the NBD polymers increased efficiently by the addition of 4,4'-bis(diethylamino)benzophenone (BEBP) as a photo-sensitizer in the film state. The stored thermal energies of the irradiated polymers were evaluated by DSC analysis to be 75-153 J/g. [DOI 10.1295/polymj.37.246]

KEY WORDS Donor-Acceptor Type Norbornadiene / Polyaddition / Photochemical Valence Isomerization / Photo-sensitizer / Stored Thermal Energy /
\end{abstract}

The photochemical valence isomerization between norbornadiene (NBD) and quadricyclane (QC) is of great interest as a solar energy conversion and storage system, ${ }^{1-4}$ because NBD can convert solar energy into $96 \mathrm{~kJ} / \mathrm{mol}$ of thermal energy through the strain in QC.

Nishikubo et al ${ }^{5-20}$ reported the synthesis of photoreactive polymers containing NBD residues in the main chain or the side chain, and it was observed that the NBD residues in the polymers converted smoothly to form QC ones. These NBD-containing polymers had high stored thermal energies. However, these synthesized polymers were not suitable to applications as a material for solar energy conversion and storage systems, because they did not have strong absorption band into visible region and did not have good durabilities in the reversible photochemical reaction.

On the other hand, it is known that donor-acceptor type norbornadiene (D-A NBD) derivatives had absorption band into visible region and converted to the corresponding QC derivatives in high quantum yield. ${ }^{21,22}$ Furthermore, Nishikubo et al. ${ }^{23-26}$ synthesized the polymers containing D-A NBD moieties in the main chain or side chain and examined their photo-chemical valence isomerization. It was found that their synthesized polymers had high photochemical reactivities and good fatigues of resistance. ${ }^{23-26}$ Furthermore, it is expected that the thermal storage energies of the polymers increase with increasing the ratio of the NBD moieties.

From these backgrounds, in this article, we examined the synthesis of the polymers containing D-A NBD moieties in the both main and side chains. The polyesters with $\mathrm{D}-\mathrm{A}$ moieties in the main chain were obtained by the polyaddition of the bisepoxides with NBD groups and carboxylic dichlorides. The substitution reaction of the obtained polyesters and potassium D-A NBD carboxylates was performed to afford the corresponding polyesters with $\mathrm{D}-\mathrm{A}$ NBD moieties in both main and side chains. Furthermore, we examined the photochemical valence isomerization of NBD and stored thermal energies, and thermal properties of the resulting polymers.

\section{EXPERIMENTAL}

\section{Materials}

5-(4-Methoxyphenyl)-1,4,6,7,7-pentamethyl-2,5norbornadiene-2,3-dicarboxylic acid (D-A NDC) (Sanpo Chemical Laboratory Ltd., Japan) was recrystallized twice from mixed solvent of chloroform/

${ }^{\dagger}$ To whom correspondence should be addressed (E-mail: nishikubot@kanagawa-u.ac.jp.). 
hexane. 5-(4-Methoxyphenyl)-1,4,6,7,7-pentamethyl2,5-NBD-2,3-dicarboxylic acid diglycidyl ester (D-A NDGE) and 5-(4-methoxyphenyl)-1,4,6,7,7-pentamethyl-2,5-norbornadiene-2,3-dicarboxylic anhydride (D-A NDCAn) were synthesized and purified according to a reported method. ${ }^{25,26} \mathrm{~A}$ mixture of 3-methoxycarbonyl-5-(4-methoxyphenyl)-1,4,6,7,7-pentamethyl-2,5-norbornadiene-2-carboxylic acid and 2-methoxycarbonyl-5-(4-methoxyphenyl)-1,4,6,7,7pentamethyl-2,5-norbornadiene-3-carboxylic acid (a) was synthesized and purified according to a reported method. ${ }^{25,26}$ In the same way, a mixture of 3-dipropylcarbamoyl-5-(4-methoxyphenyl)-1,4,6,7,7-pentamethyl-2,5-norbornadiene-2-carboxylic acid and 2-dipropylcarbamoyl-5-(4-methoxyphenyl)-1,4,6,7,7-pentamethyl-2,5-norbornadiene-3-carboxylic acid (b), and a mixture of 5-(4-methoxyphenyl)-3-methylphenylcarbamoyl-1,4,6,7,7-pentamethyl-2,5-norbornadiene2-carboxylic acid and 5-(4-methoxyphenyl)-3-methylphenylcarbamoyl-1,4,6,7,7-pentamethyl-2,5-norbornadiene-3-carboxylic acid (c) were synthesized and purified according to a reported method. ${ }^{25,26}$ Terephthaloyl chloride (TPC) and isophthaloyl chloride (IPC) were recrystallized twice from dried hexane. Succinyl chloride (SCC) and adipoyl chloride (ADC) were dried with $\mathrm{CaCl}_{2}$ and purified by distillation. Tetrabutylammonium bromide (TBAB) was recrystallized twice from dried ethyl acetate. Dicyclohexylcarbodiimide (DCC), tetrabutylammonium chloride (TBAC), tetrabutylammonium iodide (TBAI), 4,4'bis-(diethylamino)benzohenone (BEBP), and cesium carbonate $\left(\mathrm{Cs}_{2} \mathrm{CO}_{3}\right)$ were used without further purification. The solvents and 1,8-diazabicyclo[5.4.0]undecene-7 (DBU) were dried with $\mathrm{CaH}_{2}$, or Na metal wire and purified by distillation.

\section{Measurements}

Infrared (IR) spectra were measured on a Jasco Model FT/IR 420 spectrometer. Ultraviolet (UV) spectra were recorded on a Shimadzu Model UV2500PC. The ${ }^{1} \mathrm{H}$ NMR spectra were recorded on a Jeol Model JNMFX-200 (200 MHz) instrument in $\mathrm{CDCl}_{3}$ with tetramethylsilane (TMS) as an internal standard. The molecular weight of the polymers were estimated by gel permeation chromatography (GPC) with the use of a Toso Model HLC-8020 GPC equipped with a refractive index detector using TSK gel columns (eluent; THF; calibrated using narrow molecular weight polystyrenes as standards). The glass transition temperature $\left(T_{\mathrm{g}}\right)$ and the amount of stored thermal energy in the QC groups in the polymer were measured on a Seiko-Instruments differential scanning calorimeter (DSC) Model SSC5200D DSC120 at heating rate of $10^{\circ} \mathrm{C} / \mathrm{min}$.
Typical Procedure for the Synthesis of Poly(ester)s Containing D-A NBD Residues by the Polyaddition of D-A NDGE with Diacyl Chlorides: Synthesis of $P-1$ by the Polyaddition of D-A NDGE with TPC

TBAB $(16.2 \mathrm{mg}, 0.05 \mathrm{mmol})$ was dried in an ampule tube in vacuo at $60^{\circ} \mathrm{C}$ for $5 \mathrm{~h}$ prior to use. D-A NDGE (234 mg, $0.5 \mathrm{mmol})$, TPC (102 mg, $0.5 \mathrm{mmol})$, and toluene $(0.5 \mathrm{~mL})$ as the solvent were added to the ampule tube, and then the reaction mixture was degassed by three consecutive freeze-pump-thaw cycles. After that, the ampule tube was sealed, and then the reaction mixture was heated at $100^{\circ} \mathrm{C}$ for $24 \mathrm{~h}$ under stirring. The reaction mixture was diluted in ethyl acetate, washed three times with water, and dried with anhydrous $\mathrm{MgSO}_{4}$. The obtained polymer was reprecipitated twice from chloroform into ether/ hexane $(1 / 2)$ and dried in vacuo. The yield of P-1 was $302 \mathrm{mg}(90 \%)$. The number-average molecular weight $\left(M_{\mathrm{n}}\right)$ of the polymer determined by GPC was 21,000 , and the ratio of the weight-average molecular weight and the number-average molecular weight $\left(M_{\mathrm{w}} / M_{\mathrm{n}}\right)$ was 1.56. IR (film, $\left.\mathrm{cm}^{-1}\right)$ : $1728\left(v_{\mathrm{C}=\mathrm{O}}\right.$, ester), 1607 $\left(v_{\mathrm{C}=\mathrm{C}}, \mathrm{NBD}\right), 1509\left(v_{\mathrm{C}=\mathrm{C}}\right.$, aromatic $), 1265,1247$ $\left(v_{\mathrm{C}-\mathrm{O}-\mathrm{C}}\right.$, ester $), 731\left(v_{\mathrm{C}-\mathrm{Cl}}\right),{ }^{1} \mathrm{H}$ NMR $(200 \mathrm{MHz}$, $\left.\mathrm{CDCl}_{3}, \mathrm{TMS}\right): \delta(\mathrm{ppm}): 0.80-1.80\left(\mathrm{~m}, 15.0 \mathrm{H}, \mathrm{CH}_{3}\right)$, $3.60-4.00\left(\mathrm{~m}, 7.0 \mathrm{H}, \mathrm{O}-\mathrm{CH}_{3}, \mathrm{CH}_{2} \mathrm{Cl}\right), 4.40-4.70(\mathrm{~m}$, $\left.4.0 \mathrm{H}, \mathrm{O}-\mathrm{CH}_{2}\right), 5.40-5.60(\mathrm{~m}, 2.0 \mathrm{H}, \mathrm{C}-\mathrm{H}), 6.70-7.10$ $(\mathrm{m}, 4 \mathrm{H}$, aromatic $\mathrm{H}$ in $\mathrm{NBD}), 8.00-8.20(\mathrm{~m}, 4.0 \mathrm{H}$, aromatic $\mathrm{H})$.

Typical Procedure for the Synthesis of Poly(ester)s Containing D-A NBD Residues in the Both Main and Side Chains: Synthesis of P-5a by the Substitution Reaction of P-1 with a Using PTC Method

At first, potassium 5-(4-methoxyphenyl)-1,4,6,7,7pentamethyl-3-methylester-2,5-NBD-2-carboxylate (a) was prepared by the reaction of with potassium hydroxide in methanol according to the reported method. ${ }^{23,24}$ P-1 (168 mg, $0.25 \mathrm{mmol}$ ) was dissolved in $N$ methyl-2-pyrroridone (NMP; $1.0 \mathrm{~mL}$ ), and then a (306 mg, $0.75 \mathrm{mmol})$ and TBAB (16 mg, $0.025 \mathrm{mmol})$ as a phase-transfer catalyst (PTC) were added to the solution. The mixture was stirred at $70^{\circ} \mathrm{C}$ for $72 \mathrm{~h}$ and then poured into $100 \mathrm{~mL}$ of methanol to precipitate the polymer. The obtained polymer was reprecipitated twice from chloroform into methanol and dried in vacuo. The yield of P-5a was $298 \mathrm{mg}(89 \%)$. The degree of substitution was $100 \mathrm{~mol} \%$, calculated by ${ }^{1} \mathrm{H}$ NMR spectra. The $M_{\mathrm{n}}$ of the polymer determined by GPC was 14,000 , and $M_{\mathrm{w}} / M_{\mathrm{n}}$ was 1.53 . IR (film, $\left.\mathrm{cm}^{-1}\right): 1730\left(v_{\mathrm{C}=\mathrm{O}}\right.$, ester $), 1606\left(v_{\mathrm{C}=\mathrm{C}}, \mathrm{NBD}\right), 1510$ $\left(v_{\mathrm{C}=\mathrm{C}}\right.$, aromatic), 1285,1246 ( $\nu_{\mathrm{C}-\mathrm{O}-\mathrm{C}}$, ester). ${ }^{1} \mathrm{H}$ NMR $\left(200 \mathrm{MHz}, \mathrm{CDCl}_{3}, \mathrm{TMS}\right): \delta$ (ppm): 0.70-2.15 (m, $\left.45.0 \mathrm{H}, \mathrm{CH}_{3}\right), 3.52-4.00\left(\mathrm{~m}, 15.0 \mathrm{H}, \mathrm{O}-\mathrm{CH}_{3}\right), 4.08-$ $4.75\left(\mathrm{~m}, 8.0 \mathrm{H}, \mathrm{O}-\mathrm{CH}_{2}\right), 5.40-5.74(\mathrm{~m}, 2.0 \mathrm{H}, \mathrm{C}-\mathrm{H})$, 


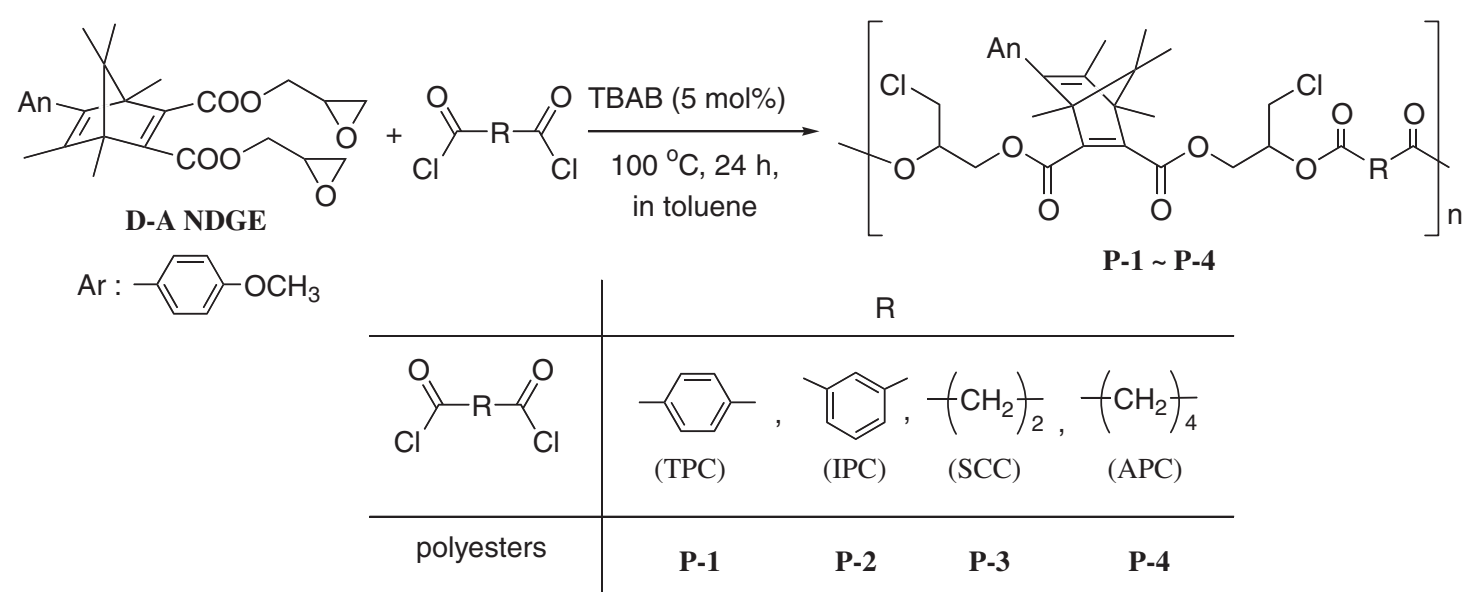

Scheme 1.

6.68-7.20 ( $\mathrm{m}, 12.0 \mathrm{H}$, aromatic $\mathrm{H}$ in NBD), 7.86-8.14 (m, $4.0 \mathrm{H}$, aromatic $\mathrm{H}$ in the main chain).

\section{Typical Procedure for the Photo-isomerization of NBD Polymer in Solution}

A quartz cell was charged with a solution of a NBD polymer in THF $\left(1.0 \times 10^{-4} \mathrm{~mol} / \mathrm{L}\right.$ as NBD residues), and then the solution was irradiated with a $500-\mathrm{W}$ xenon lamp (Ushio Electric Co. UXL-500D-O) with a thermal-ray cut filter (Hoya HA50), in which the energy of the incident light $\left(2.00-2.10 \mathrm{~mW} / \mathrm{cm}^{2}, 313 \mathrm{~nm}\right)$ was monitored with an electric photon counter (ORC UV-M30). The disappearance rate of the absorption due to the NBD residue was measured with a UV spectrophotometer.

Typical Procedure for the Photo-isomerization of NBD Residue in Polymer Film

The inner wall of a quartz cell was coated with a solution of a polymer $(2 \mathrm{mg})$ in THF $(2 \mathrm{~mL})$ and dried in vасио at room temperature for $2 \mathrm{~h}$. The polymer film on the quartz cell was irradiated with the same xenon lamp with a thermal-ray cut filter. The conversion and photo-isomerization rates from NBD residues to QC groups were calculated from the disappearance of the maximum absorption of the NBD residue, as measured with an UV spectrophotometer.

\section{Measurement of Stored Thermal Energy in the $Q C$ Group in the Polymer}

A polymer solution in THF was cast on a glass plate and dried in vacuo for $2 \mathrm{~h}$. The film on the plate was irradiated with a 500-W xenon lamp long enough to be changed from the NBD residue to the QC group. The irradiated polymer $(5 \mathrm{mg})$ was packed in an aluminum sample tube for DSC analysis, and the sample was heated at $10^{\circ} \mathrm{C} / \mathrm{min}$ under nitrogen.

\section{RESULTS AND DISCUSSION}

Synthesis of Poly(ester)s Containing D-A NBD Residues by the Polyaddition of D-A NDGE with Diacyl Chlorides

The polyaddition of D-A NDGE with TPC was performed in certain organic solvents such as toluene, $o$ dichlorobenzene, NMP, or sulfolane with $2.5 \mathrm{~mol} \%$ of $\mathrm{TBAB}$ as a catalyst at $100^{\circ} \mathrm{C}$ for $12 \mathrm{~h}$ (Scheme 1), and the results are summarized in Table I. In toluene and $o$-dichlorobenzene, polymers with higher molecular weights than in NMP and sulfolane were obtained. These results might be indicated that a slight amount of water which can not be removed under distillation caused hydrolysis of the ester moieties of the synthesized polymers. Consequently, it seems that hydrophobic and aromatic solvents such as toluene and $o_{-}$ dichlorobenzene are suitable reaction media for the polyaddition of D-A NDGE with TPC to synthesize the corresponding polyesters.

The structure of the resulting NBD polyester (P-1) was confirmed by IR and ${ }^{1} \mathrm{H}$ NMR spectra (Table II). In the IR spectrum of $\mathrm{P}-1$, certain characteristic ab-

Table I. Effect of solvents on the polyaddition of D-A NDGE with TPC ${ }^{\mathrm{a}}$

\begin{tabular}{ccccc}
\hline No. & Solvent & $\begin{array}{c}\text { Yield } \\
(\%)^{\mathrm{b}}\end{array}$ & $M_{\mathrm{n}} \times 10^{-3 \mathrm{c}}$ & $M_{\mathrm{w}} / M_{\mathrm{n}}{ }^{\mathrm{c}}$ \\
\hline 1 & Toluene & 89 & 5.5 & 1.34 \\
2 & $o$-Dichlorobenzene & 77 & 4.1 & 1.33 \\
3 & NMP & 73 & 2.9 & 1.27 \\
4 & Sulforane & 70 & 2.3 & 1.26 \\
\hline
\end{tabular}

${ }^{\mathrm{a}}$ The reaction was carried out with D-A NDGE $(0.5 \mathrm{mmol})$ and TPC $(0.5 \mathrm{mmol})$ using $2.5 \mathrm{~mol} \%$ of TBAB in various solvents at $100^{\circ} \mathrm{C}$ for $12 \mathrm{~h}$. ${ }^{\mathrm{b}}$ Insoluble parts in mixed solvents of $\mathrm{Et}_{2} \mathrm{O} /$ hexane $[1 / 2(\mathrm{v} / \mathrm{v})]$. ${ }^{c}$ Estimated by GPC (THF) based on polystyrene standards. 
Table II. IR and ${ }^{1} \mathrm{H}$ NMR spectral data of the resulting polymers

\begin{tabular}{|c|c|c|}
\hline Polymer & IR spectral data (film, $\mathrm{cm}^{-1}$ ) & ${ }^{1} \mathrm{H}$ NMR spectral data $[200 \mathrm{MHz}, \mathrm{CDCl} 3, \mathrm{TMS}, \delta(\mathrm{ppm})]$ \\
\hline $\mathrm{P}-1$ & $\begin{array}{l}1728(\mathrm{C}=\mathrm{O} \text { ester }), 1607(\mathrm{C}=\mathrm{C} \text { NBD}), \\
1577,1509(\mathrm{C}=\mathrm{C} \text { aromatic }), \\
1265,1247(\mathrm{C}-\mathrm{O}-\mathrm{C} \text { ester }), 731(\mathrm{C}-\mathrm{Cl})\end{array}$ & $\begin{array}{l}0.80-1.80\left(15.0 \mathrm{H},-\mathrm{CH}_{3}\right), 3.60-4.00\left(7.0 \mathrm{H},-\mathrm{O}-\mathrm{CH}_{3},\right. \\
\left.-\mathrm{CH}_{2} \mathrm{Cl}\right), 4.40-4.70\left(4.0 \mathrm{H},-\mathrm{O}-\mathrm{CH}_{2}-\right), 5.40-5.60(2.0 \mathrm{H}, \\
-\mathrm{CH}-), 6.70-7.10(4.0 \mathrm{H}, \text { aromatic } \mathrm{H} \text { in NBD }) \\
8.00-8.20(4.0 \mathrm{H}, \text { aromatic } \mathrm{H})\end{array}$ \\
\hline $\mathrm{P}-2$ & $\begin{array}{l}1730(\mathrm{C}=\mathrm{O} \text { ester }), 1607(\mathrm{C}=\mathrm{C} \text { NBD}), \\
1569,1509(\mathrm{C}=\mathrm{C} \text { aromatic }), \\
1287,1232(\mathrm{C}-\mathrm{O}-\mathrm{C} \text { ester }), 728(\mathrm{C}-\mathrm{Cl})\end{array}$ & $\begin{array}{l}0.80-1.80\left(15.0 \mathrm{H},-\mathrm{CH}_{3}\right), 3.60-4.00\left(6.0 \mathrm{H},-\mathrm{O}-\mathrm{CH}_{3},\right. \\
\left.-\mathrm{CH}_{2} \mathrm{Cl}\right), 4.40-4.70\left(4.0 \mathrm{H},-\mathrm{O}-\mathrm{CH}_{2}-\right), 5.40-5.60(2.0 \mathrm{H}, \\
-\mathrm{CH}-), 6.70-7.10(4.0 \mathrm{H} \text {, aromatic } \mathrm{H} \text { in } \mathrm{NBD}), \\
7.40-7.60(1.0 \mathrm{H}, \text { aromatic } \mathrm{H}) 8.10-8.40(2.0 \mathrm{H} \text {, aromatic } \\
\mathrm{H}), 8.60-8.70(1.0 \mathrm{H} \text {, aromatic } \mathrm{H})\end{array}$ \\
\hline $\mathrm{P}-3$ & $\begin{array}{l}1741(\mathrm{C}=\mathrm{O} \text { ester }), 1606(\mathrm{C}=\mathrm{C} \text { NBD}), \\
1570,1509(\mathrm{C}=\mathrm{C} \text { aromatic }), \\
1245,1227(\mathrm{C}-\mathrm{O}-\mathrm{C} \text { ester }), 758(\mathrm{C}-\mathrm{Cl})\end{array}$ & $\begin{array}{l}0.80-1.80\left(15.0 \mathrm{H},-\mathrm{CH}_{3}\right), 2.60-2.80\left(4.0 \mathrm{H}, \mathrm{CO}-\mathrm{CH}_{2}-\right) \\
3.60-4.00\left(7.0 \mathrm{H},-\mathrm{O}-\mathrm{CH}_{3},-\mathrm{CH}_{2} \mathrm{Cl}\right), 4.40-4.70(4.0 \mathrm{H}, \\
\left.-\mathrm{O}-\mathrm{CH}_{2}-\right), 5.40-5.60(2.0 \mathrm{H},-\mathrm{CH}-), 6.70-7.10(4.0 \mathrm{H}, \\
\text { aromatic } \mathrm{H} \text { in NBD) }\end{array}$ \\
\hline P-4 & $\begin{array}{l}1740(\mathrm{C}=\mathrm{O} \text { ester }), 1606(\mathrm{C}=\mathrm{C} \text { NBD}), \\
1571,1509(\mathrm{C}=\mathrm{C} \text { aromatic }) \\
1245,1223(\mathrm{C}-\mathrm{O}-\mathrm{C} \text { ester }), 758(\mathrm{C}-\mathrm{Cl})\end{array}$ & $\begin{array}{l}0.80-1.80\left(19.0 \mathrm{H},-\mathrm{CH}_{3}, \mathrm{C}-\mathrm{CH}_{2}-\mathrm{C}\right), 2.20-2.40(4.0 \mathrm{H}, \\
\left.\mathrm{CO}-\mathrm{CH}_{2}\right) 3.60-4.00\left(7.0 \mathrm{H},-\mathrm{O}-\mathrm{CH}_{3},-\mathrm{CH}_{2} \mathrm{Cl}\right), \\
4.40-4.70\left(4.0 \mathrm{H},-\mathrm{O}-\mathrm{CH}_{2}-\right), 5.40-5.60(2.0 \mathrm{H},-\mathrm{CH}-), \\
6.70-7.10(4.0 \mathrm{H}, \text { aromatic } \mathrm{H} \text { in NBD })\end{array}$ \\
\hline
\end{tabular}



Figure 1. Effect of temperature on the polyaddition of D-A NDGE $(0.5 \mathrm{mmol})$ with TPC $(0.5 \mathrm{mmol})$ with TBAB $(2.5 \mathrm{~mol} \%)$ in toluene $(0.5 \mathrm{~mL})$ for $12 \mathrm{~h}$ : $(\square)$ yield and $(\bullet) M_{\mathrm{n}}$ of the polymer.

sorption peaks showed at $1728(\mathrm{C}=\mathrm{O}$ stretching $)$, $1607(\mathrm{C}=\mathrm{C}$ stretching), 1265 and $1247(\mathrm{C}-\mathrm{O}-\mathrm{C}$ stretching), and 731 (C-Cl stretching). In the ${ }^{1} \mathrm{H}$ NMR spectrum of $\mathrm{P}-1$, the corresponding proton signals were observed at $0.80-1.80\left(\mathrm{CH}_{3}\right), 3.60-4.00$ $\left(\mathrm{O}-\mathrm{CH}_{3}, \quad \mathrm{CH}_{2} \mathrm{Cl}\right), \quad 4.40-4.70 \quad\left(\mathrm{O}-\mathrm{CH}_{2}\right), \quad 5.40-5.60$ (C- $\underline{\mathrm{H}}), 6.70-7.10$ (aromatic $\underline{\mathrm{H}}$ in NBD), and 8.008.20 (aromatic $\underline{H}$ in the main chain), respectively. This shows that $\mathrm{P}-1$ with pendant chloromethyl groups in the side chain was synthesized by the regioselective polyaddition of epoxide groups in D-A NDGE with TPC as shown in Scheme 1. That is, $\beta$-cleavage of the epoxide groups occurred selectively to form the NBD polymer in this polyaddition.

The effect of the reaction temperature on the poly-

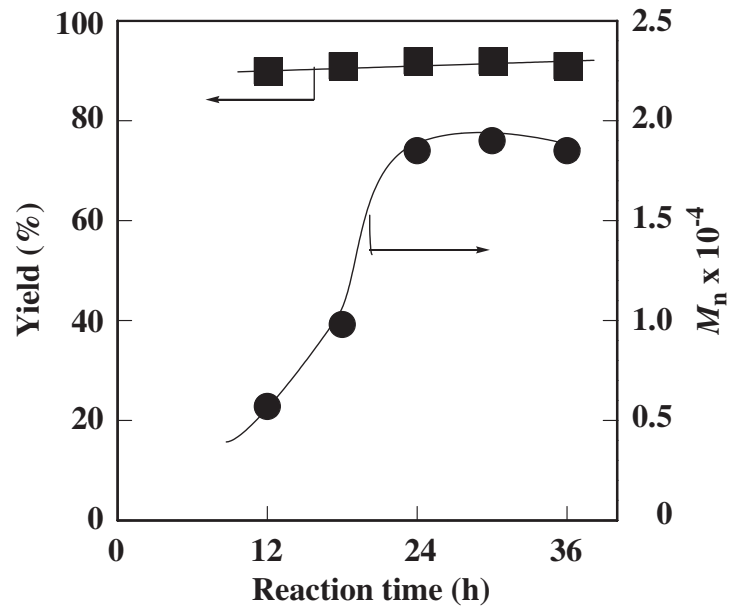

Figure 2. Effect of time on the polyaddition of D-A NDGE $(0.5 \mathrm{mmol})$ with TPC $(0.5 \mathrm{mmol})$ with TBAB $(2.5 \mathrm{~mol} \%)$ in toluene $(0.5 \mathrm{~mL})$ at $100^{\circ} \mathrm{C}:(\square)$ yield and $(\bullet) M_{\mathrm{n}}$ of the polymer.

addition of D-A NDGE with TPC was investigated with $2.5 \mathrm{~mol} \%$ of TBAB as the catalyst in toluene for $12 \mathrm{~h}$ at $60-100{ }^{\circ} \mathrm{C}$ (Figure 1). The yields and $M_{\mathrm{n}} \mathrm{s}$ of the resulting polymers increased gradually with temperature. This suggests that $100^{\circ} \mathrm{C}$ is an appropriate temperature for the polyaddition of D-A NDGE with TPC.

The effect of varying the reaction time on the polyaddition of D-A NDGE with TPC was also examined using $2.5 \mathrm{~mol} \%$ of TBAB as a catalyst in toluene at $100{ }^{\circ} \mathrm{C}$ for $12-36 \mathrm{~h}$. The polymers were obtained in good yields all points, as shown in Figure 2. On the other hand, the $M_{\mathrm{n}} \mathrm{s}$ of the resulting polymer increased for $24 \mathrm{~h}$.

The polyaddition of D-A NDGE with TPC was also 
Table III. Effect of catalysts on the polyaddition of D-A NDGE with TPC ${ }^{\mathrm{a}}$

\begin{tabular}{lrcc}
\hline Catalysts & $\begin{array}{c}\text { Yield } \\
(\%)^{\mathrm{b}}\end{array}$ & $M_{\mathrm{n}} \times 10^{-4 \mathrm{c}}$ & $M_{\mathrm{w}} / M_{\mathrm{n}}{ }^{\mathrm{c}}$ \\
\hline None & 0 & - & - \\
DBU & 52 & 0.3 & 1.40 \\
TBAC & 92 & 1.5 & 1.57 \\
TBAB & 91 & 1.8 & 1.70 \\
TBAI & 91 & 0.9 & 1.86 \\
\hline
\end{tabular}

${ }^{\mathrm{a}}$ The reaction was carried out with D-A NDGE $(0.5 \mathrm{mmol})$ and TPC $(0.5 \mathrm{mmol})$ using various catalysts $(2.5 \mathrm{~mol} \%)$ in toluene $(1 \mathrm{~mol} / \mathrm{L})$ at $100{ }^{\circ} \mathrm{C}$ for $24 \mathrm{~h} .{ }^{b}$ Insoluble parts in mixed solvents of $\mathrm{Et}_{2} \mathrm{O} /$ hexane $[1 / 2(\mathrm{v} / \mathrm{v})]$. ${ }^{\mathrm{c}}$ Estimated by GPC (THF) based on polystyrene standards.

examined with certain other catalysts or without any catalyst in toluene at $100^{\circ} \mathrm{C}$ for $24 \mathrm{~h}$, and the results are summarized in Table III. When the reaction was carried out without catalyst, no polymer was obtained. When the reaction was carried out using DBU as a catalyst, P-1 with $M_{\mathrm{n}}=3000$ was obtained in $52 \%$ yield. On the other hand, when the polyaddition of D-A NDGE with TPC was carried out with 2.5 mol $\%$ of certain quaternary onium salts as catalysts (TBAC, TBAB, or TBAI) (Table III), P-1s with relatively high molecular weights (e.g., $M_{\mathrm{n}}=9000$ 18000 ) were obtained in $91-92 \%$ yields. In a similar manner with the polyaddition of D-A NDGE with $\mathrm{TPC}$, the catalyst with bromide (TBAB) showed the highest catalytic activity, because of the good balance of nucleophilicity toward epoxy groups and the leaving ability of the intermediate. These results show that the polyaddition of D-A NDGE with TPC proceed smoothly using quaternary onium salts such as TBAB.

The effect of catalyst concentration on the polyaddition of D-A NDGE with TPC was also investigated using TBAB as a catalyst in toluene at $100^{\circ} \mathrm{C}$ for $24 \mathrm{~h}$. As shown in Figure 3, the yields of P-1 increased from 1 to $2.5 \mathrm{~mol} \%$ with the catalyst concentration. On the other hand, although the $M_{\mathrm{n}} \mathrm{s}$ of the obtained polymer increased from 2.5 to $5 \mathrm{~mol} \%$ with catalyst

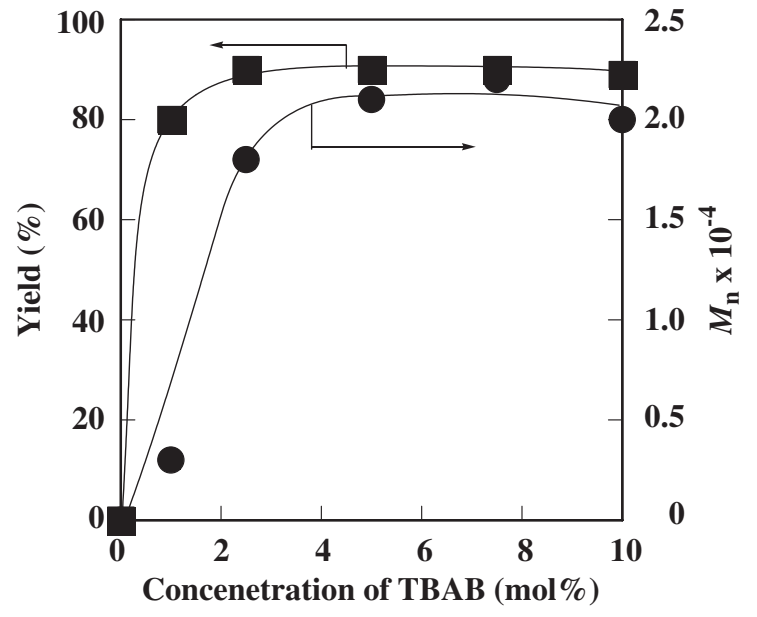

Figure 3. Effect of $\mathrm{TBAB}$ concentration on the polyaddition of D-A NDGE $(0.5 \mathrm{mmol})$ with TPC $(0.5 \mathrm{mmol})$ with TBAB in toluene $(0.5 \mathrm{~mL})$ at $100^{\circ} \mathrm{C}$ for $24 \mathrm{~h}$ : (ם) yield and (๑) $M_{\mathrm{n}}$ of the polymer.

concentration, the $M_{\mathrm{n}}$ of the polymer did not change with more than $5 \mathrm{~mol} \%$ of TBAB. This suggests that $5 \mathrm{~mol} \%$ of TBAB is an appropriate catalyst concentration for the polyaddition of D-A NDGE with TPC.

On the basis of the results shown above, certain poly(ester)s (P-2, P-3 and P-4) with NBD moieties in the main chain and pendant chloromethyl groups were synthesized by the polyaddition of D-A NDGE with diacyl chlorides IPC, SCC, and, APC with 5 mol $\%$ of TBAB as a catalyst in toluene at $100{ }^{\circ} \mathrm{C}$ for $24 \mathrm{~h}$. As summarized in Table IV, each reaction proceeded smoothly, and the corresponding poly(ester)s P-2, P-3 and P-4 with $M_{\mathrm{n}}$ s of 14,000, 5,000 and 6,000 were obtained in 76,72 and $70 \%$ yields, respectively. The IR and ${ }^{1} \mathrm{H}$ NMR spectroscopic data of the obtained polymers proved that the polyaddition of D-A NDGE with IPC, SCC, and APC proceeded smoothly and regioselectively to give the corresponding poly(ester)s P-2, P-3 and P-4, as shown in Scheme 2.

\section{Chemical Modification of P-1 Using PTC Method}

The chemical modification of $\mathrm{P}-1$, which contained

Table IV. Synthesis of NBD polymers by the polyaddition of D-A NDGE with various diacyl chlorides ${ }^{\mathrm{a}}$

\begin{tabular}{cccccccc}
\hline Polymer & Diacyl chloride & $\begin{array}{c}\text { Yield } \\
(\%)^{\mathrm{b}}\end{array}$ & $M_{\mathrm{n}} \times 10^{-4 \mathrm{c}}$ & $M_{\mathrm{w}} / M_{\mathrm{n}}{ }^{\mathrm{c}}$ & $\begin{array}{c}\lambda_{\max } \\
(\mathrm{nm})^{\mathrm{d}}\end{array}$ & $\begin{array}{c}\lambda_{\text {edge }} \\
(\mathrm{nm})^{\mathrm{d}}\end{array}$ & $\begin{array}{c}\text { Selectively } \\
\alpha: \beta\end{array}$ \\
\hline P-1 & TPC & 91 & 2.1 & 1.56 & 244,330 & 420 & $0: 100$ \\
P-2 & IPC & 76 & 1.4 & 1.51 & 230,330 & 420 & $0: 100$ \\
P-3 & SCC & 72 & 0.5 & 1.47 & 250,320 & 430 & $0: 100$ \\
P-4 & ADC & 70 & 0.6 & 1.51 & 250,320 & 420 & $0: 100$ \\
\hline
\end{tabular}

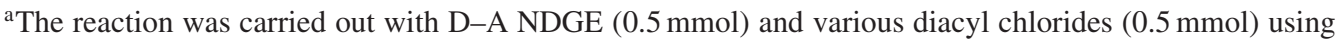
$\operatorname{TBAB}(5 \mathrm{~mol} \%)$ in toluene $(1 \mathrm{~mol} / \mathrm{L})$ at $100{ }^{\circ} \mathrm{C}$ for $24 \mathrm{~h}$. ${ }^{\mathrm{b}}$ Insoluble parts in mixed solvents of $\mathrm{Et}_{2} \mathrm{O} / \mathrm{hexane}$ $[1 / 2(\mathrm{v} / \mathrm{v})] .{ }^{\mathrm{c}}$ Estimated by GPC (THF) based on polystyrene standards. ${ }^{\mathrm{d}}$ Measured by UV spectrophotometer in the film state. ${ }^{\mathrm{e}}$ Datemined by ${ }^{1} \mathrm{H}$ NMR spectrum. 


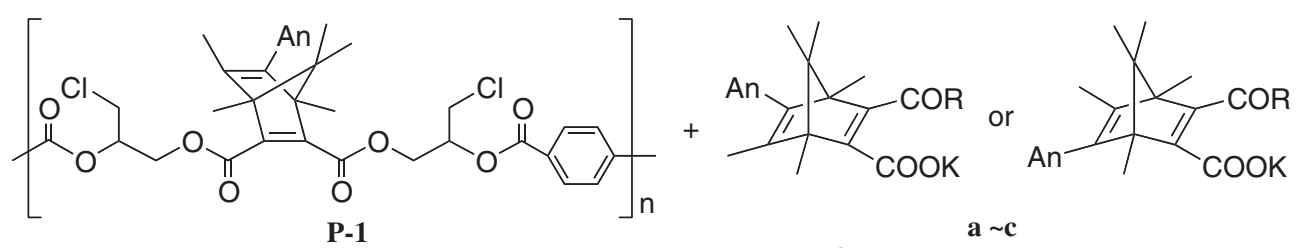<smiles>COc1ccc(C)cc1</smiles>

$\mathrm{a}: \mathrm{R}=\mathrm{OMe}, \mathrm{b}: \mathrm{R}=\mathrm{NPr}_{2}$, $\mathrm{c}: \mathrm{R}=\mathrm{NMePh}$
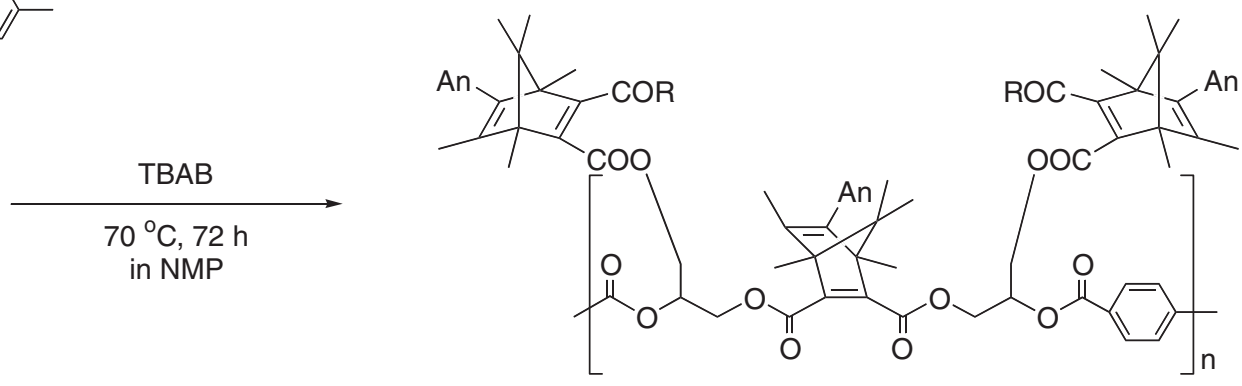

P-5a $\sim \mathbf{c}$

$\mathrm{P}-5 \mathrm{a}: \mathrm{R}=\mathrm{OMe}, \mathrm{P}-5 \mathrm{~b}: \mathrm{R}=\mathrm{NPr}_{2}, \mathrm{P}-5 \mathrm{c}: \mathrm{R}=\mathrm{NMePh}$

Scheme 2.

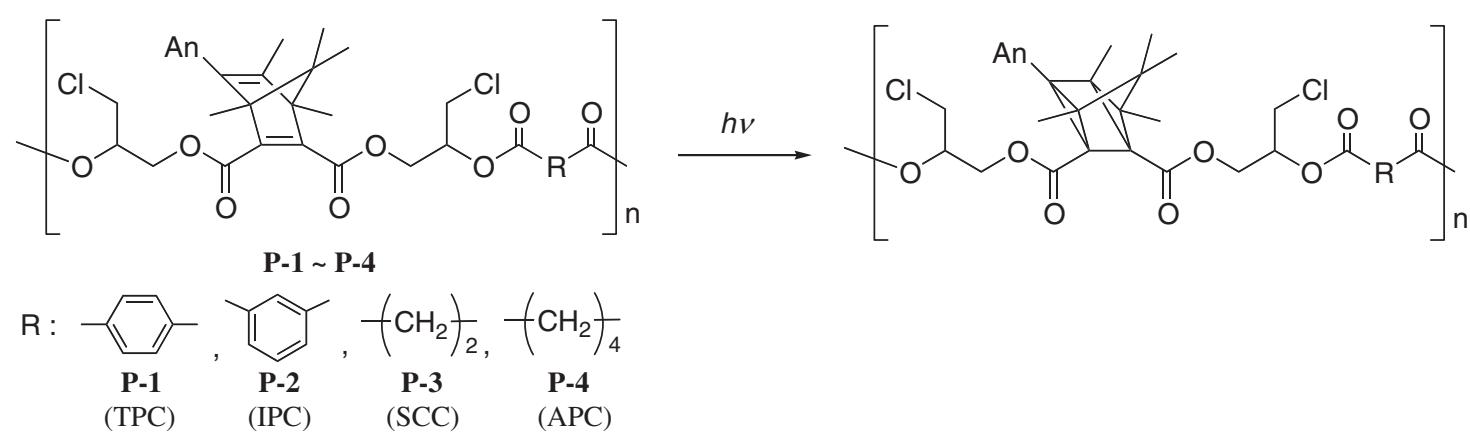

Scheme 3.

Table V. Synthesis and properties of NBD polymers ${ }^{\mathrm{a}}$

\begin{tabular}{clcccccc}
\hline Polym. & \multicolumn{1}{c}{$\mathrm{R}$} & $\begin{array}{c}\text { D.S. }^{\mathrm{b}} \\
(\%)\end{array}$ & $\begin{array}{c}\text { Yield }^{\mathrm{c}} \\
(\%)\end{array}$ & $M_{\mathrm{n}} \times 10^{-4 \mathrm{~d}}$ & $M_{\mathrm{w}} / M_{\mathrm{n}}{ }^{\mathrm{d}}$ & $\begin{array}{c}\lambda_{\max }{ }^{\mathrm{e}} \\
(\mathrm{nm})\end{array}$ & $\begin{array}{c}\lambda_{\text {edge }}{ }^{\mathrm{e}} \\
(\mathrm{nm})\end{array}$ \\
\hline P-5a & $-\mathrm{OMe}$ & 100 & 87 & 1.0 & 1.53 & $244,288,322$ & 437 \\
$\mathrm{P}-5 \mathrm{~b}$ & $-\mathrm{NPr}_{2}$ & 100 & 75 & 0.8 & 1.53 & $243,287,322$ & 430 \\
$\mathrm{P}-5 \mathrm{c}$ & $-\mathrm{NmePh}$ & 100 & 78 & 1.0 & 1.46 & $245,286,324$ & 436 \\
\hline
\end{tabular}

${ }^{\mathrm{a}}$ The reaction was carried out with P-1 $(0.25 \mathrm{mmol})$ and potassium D-A NBD carboxylates $(0.75 \mathrm{mmol})$

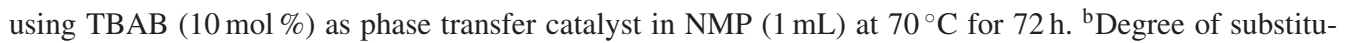
tion was calculated by ${ }^{1} \mathrm{H}$ NMR. ${ }^{\mathrm{c}}$ Insoluble parts in $n$-hexane. ${ }^{\mathrm{d}}$ Estimated by GPC based on polystyrene standards in THF. ${ }^{e}$ Measured by UV spectrophotometer in the film state.

reactive pendant chloromethyl groups, was examined with 1.5 equivalents of $\mathrm{D}-\mathrm{A}$ NBD derivatives $\mathbf{a}, \mathbf{b}$ and $\mathbf{c}$ using TBAB as a PTC in NMP at $70^{\circ} \mathrm{C}$ for 72 $\mathrm{h}$ (Scheme 3). The reaction proceeded smoothly under this reaction conditions, and the corresponding polymers $(\mathrm{P}-5 \mathrm{a}-\mathrm{c})$ containing $100 \mathrm{~mol} \%$ of the pendant D-A NBD moieties were obtained in good yields (Table V). The degree of substitution of the polymers was confirmed by the intensity ratio of the ${ }^{1} \mathrm{H}$ NMR spectrum (Table VI). This means that $\mathrm{P}-1$ with reactive pendant chloromethyl groups in the side chain is still more possible for functionizing by introduction of not only NBD residues but sensitizing groups, etc.

Photo-isomerization of the NBD Poly(ester)s in the Film State and in THF Solution

The photochemical valence isomerization of poly(ester)s, P-1-P-4, containing NBD moieties in the main chain was carried out in the films states and in THF solutions upon irradiation with a 500-W xenon lamp (Scheme 3). As shown in Figure 4, maximum absorption at $244 \mathrm{~nm}$ due to the NBD moiety in P-1 
Table VI. IR and ${ }^{1} \mathrm{H}$ NMR spectral data of the resulting polymers

\begin{tabular}{|c|c|c|}
\hline Polymer & IR spectral data (film, $\mathrm{cm}^{-1}$ ) & ${ }^{1} \mathrm{H}$ NMR spectral data $\left[200 \mathrm{MHz}, \mathrm{CDCl}_{3}, \mathrm{TMS}, \delta(\mathrm{ppm})\right]$ \\
\hline $\mathrm{P}-5 \mathrm{a}$ & $\begin{array}{l}1730(\mathrm{C}=\mathrm{O} \text { ester }), 1606(\mathrm{C}=\mathrm{C} \text { NBD }) \\
1510(\mathrm{C}=\mathrm{C} \text { aromatic }), 1285,1246 \\
(\mathrm{C}-\mathrm{O}-\mathrm{C} \text { ester })\end{array}$ & $\begin{array}{l}0.70-2.15\left(45.0 \mathrm{H},-\mathrm{CH}_{3}\right), 3.50-4.00\left(15.0 \mathrm{H},-\mathrm{O}-\mathrm{CH}_{3},\right), \\
4.10-4.75\left(8.0 \mathrm{H},-\mathrm{O}-\mathrm{CH}_{2}-\right), 5.40-5.70(2.0 \mathrm{H},-\mathrm{CH}-), \\
6.70-7.20(12.0 \mathrm{H} \text {, aromatic H in NBD), } 7.90-8.10(4.0 \mathrm{H} \text {, } \\
\text { aromatic } \mathrm{H})\end{array}$ \\
\hline $\mathrm{P}-5 \mathrm{~b}$ & $\begin{array}{l}1716(\mathrm{C}=\mathrm{O} \text { ester }), 1623(\mathrm{C}=\mathrm{O} \text { amide }) \\
1607(\mathrm{C}=\mathrm{C} \text { NBD }), 1509(\mathrm{C}=\mathrm{C} \\
\text { aromatic }), 1284,1245(\mathrm{C}-\mathrm{O}-\mathrm{C} \text { ester })\end{array}$ & $\begin{array}{l}0.30-1.90\left(65.2 \mathrm{H},-\mathrm{CH}_{3} \text { in } \mathrm{NBD},-\mathrm{C}-\mathrm{CH}_{2}-\mathrm{CH}_{3}\right), \\
2.50-3.90\left(17.1 \mathrm{H},-\mathrm{O}-\mathrm{CH}_{3},-\mathrm{N}-\mathrm{CH}_{2}-\right), 4.20-4.80(8.0 \mathrm{H} \text {, } \\
\left.-\mathrm{O}-\mathrm{CH}_{2}-\right), 5.40-5.70(2.0 \mathrm{H},-\mathrm{CH}-), 6.70-7.40(12.0 \mathrm{H} \text {, } \\
\text { aromatic } \mathrm{H} \text { in NBD), 8.00-8.20 (4.0H, aromatic } \mathrm{H})\end{array}$ \\
\hline $\mathrm{P}-5 \mathrm{c}$ & $\begin{array}{l}1723(\mathrm{C}=\mathrm{O} \text { ester }), 1635(\mathrm{C}=\mathrm{O} \text { amide }) \\
1606(\mathrm{C}=\mathrm{C} \text { NBD }), 1509(\mathrm{C}=\mathrm{C} \\
\text { aromatic }), 1284,1247(\mathrm{C}-\mathrm{O}-\mathrm{C} \text { ester })\end{array}$ & $\begin{array}{l}0.50-2.00\left(45.0 \mathrm{H},-\mathrm{CH}_{3}\right), 3.00-4.00\left(15.0 \mathrm{H},-\mathrm{O}-\mathrm{CH}_{3},\right. \\
\left.-\mathrm{N}-\mathrm{CH}_{3}\right), 4.10-4.80\left(8.0 \mathrm{H},-\mathrm{O}-\mathrm{CH}_{2}-\right), 5.40-5.70(2.0 \mathrm{H} \text {, } \\
-\mathrm{CH}-), 6.60-7.60(22.0 \mathrm{H}, \text { aromatic } \mathrm{H} \text { in } \mathrm{NBD}), \\
7.70-8.10(4.0 \mathrm{H}, \text { aromatic } \mathrm{H})\end{array}$ \\
\hline
\end{tabular}

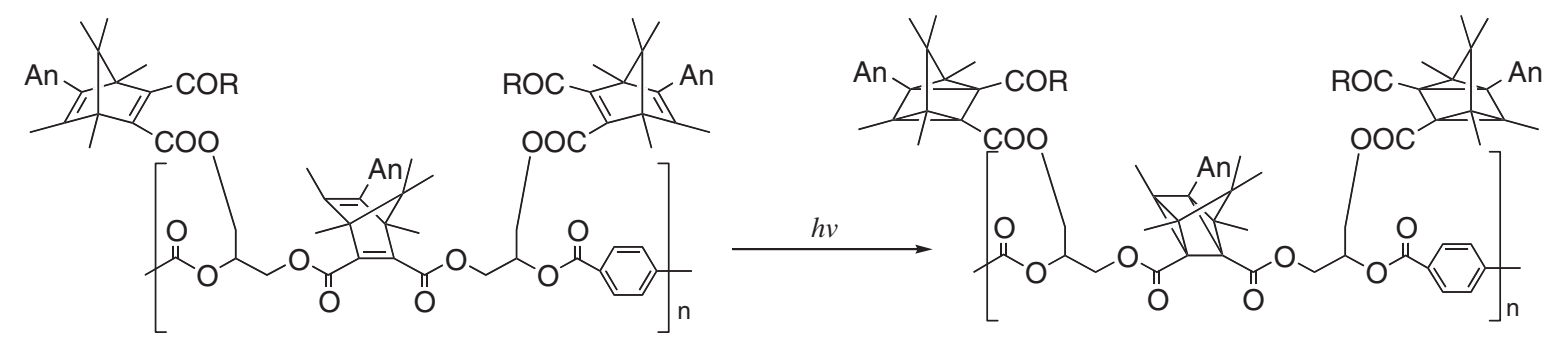

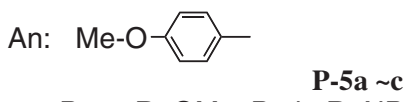

$\mathrm{P}-5 \mathrm{a}: \mathrm{R}=\mathrm{OMe}, \mathrm{P}-5 \mathrm{~b}: \mathrm{R}=\mathrm{NPr}_{2}, \mathrm{P}-5 \mathrm{c}: \mathrm{R}=\mathrm{NMePh}$

Scheme 4.

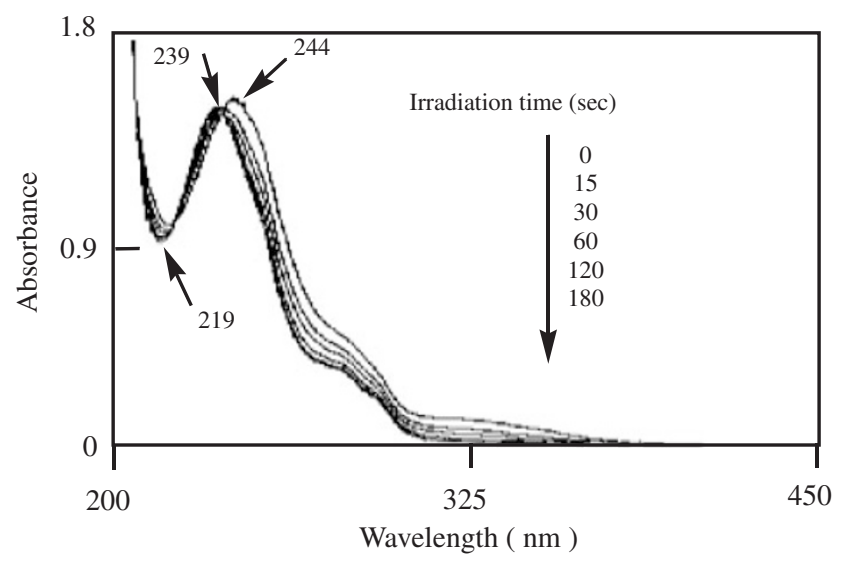

Figure 4. Change of UV spectra of P-1 in the film state upon UV irradiation with 500-W xenon lamp.

decreased gradually with UV irradiation, and the NBD moiety isomerized quantitatively to the QC group for 3 min irradiation. In addition, two isosbestic points at 219 and $239 \mathrm{~nm}$ were observed in the UV spectra. This means that the photochemical valence isomerization of the NBD residues in P-1 to the corresponding QC groups occurred selectively without any side reactions.

The UV spectral changes of $\mathrm{P}-1-\mathrm{P}-4$ were also

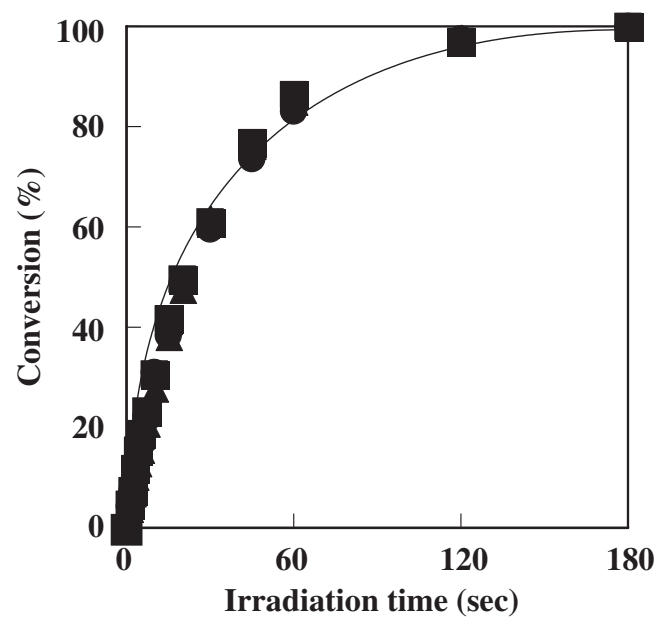

Figure 5. Time-conversion curve of photoisomerization of NBD polymers in THF solution: $(\boldsymbol{\square}) \mathrm{P}-1,(\bullet) \mathrm{P}-2,(\mathbf{\Delta}) \mathrm{P}-3,(\boldsymbol{\nabla})$ P-4.

measured under the UV-irradiation condition, and the conversions from the NBD moieties to the QC groups were calculated from the decrease of the optical densities of the NBD moieties. As shown in Figure 5, all the polymers with D-A NBD residues (P-1-P-4) had very high photochemical reactivity and isomerized very smoothly to the corresponding 


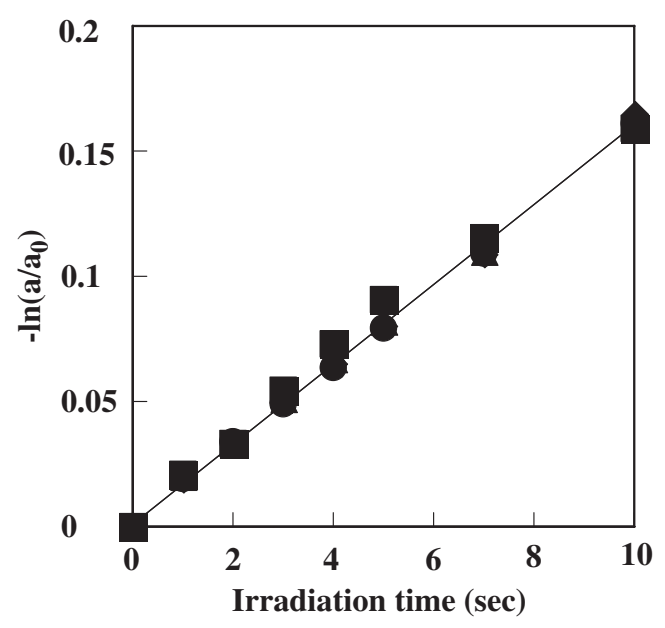

Figure 6. First-order plots of photoisomerization of NBD



Table VII. First-order photoisomerization rate constants of NBD polymers ${ }^{\mathrm{a}}$

\begin{tabular}{lcccc}
\hline & \multicolumn{4}{c}{$k_{\text {obsd }} \times 10^{2}\left(\mathrm{~s}^{-1}\right)$} \\
Polymer \\
\cline { 2 - 5 } & in THF solution $^{\mathrm{b}}{ }^{\text {in the film state }}$ & $\begin{array}{c}\text { with BEBP } \\
\left(k_{1}\right)\end{array}$ & $k_{2} / k_{1}$ \\
\hline P-1 & 1.42 & 1.63 & 15.76 & \\
P-2 & 1.31 & 1.68 & 15.06 & 8.7 \\
P-3 & 1.41 & 1.67 & 12.51 & 7.5 \\
P-4 & 1.28 & 1.65 & 14.52 & 8.8 \\
P-5a & 1.44 & 1.51 & 9.01 & 6.0 \\
P-5b & 1.36 & 1.40 & 10.86 & 7.8 \\
P-5c & 1.38 & 1.42 & 9.50 & 6.7 \\
\hline
\end{tabular}

${ }^{a}$ Irradiated by a $500-\mathrm{W}$ xenon lamp. Intensity: $2.0-2.1 \mathrm{~mW} /$ $\mathrm{cm}^{2}$ at $313 \mathrm{~nm}$. ${ }^{\mathrm{b}}$ Concentration: $1 \times 10^{-4} \mathrm{~mol} / \mathrm{L}$. ${ }^{\mathrm{c}}$ Added 10 mol $\%$ of BEBP for NBD moieties in the polymer film.

QC groups only for $3 \mathrm{~min}$. In addition, as shown in Figure 6 , the observed rates of photoisomerization $\left(\ln \left(a / a_{0}\right)\right)$ of the NBD moieties in P-1-P-4 obeyed first-order kinetics in the initial reaction stage. The rate constants of photochemical isomerization of $\mathrm{P}-1-\mathrm{P}-4$ in the films states and in THF solution are summarized in Table VII.

Furthermore, the photochemical valence isomerization of P-5a-P-5c containing both in the main and the side chain was also examined in the films states and in THF solutions under the same irradiation conditions (Scheme 4). As shown in Figure 7, NBD moieties in $\mathrm{P}-5 \mathrm{a}-\mathrm{P}-5 \mathrm{c}$ isomemerized similarly to $\mathrm{P}-1-\mathrm{P}-4$ to the QC moiety for $3 \mathrm{~min}$. Interestingly enough, in spite of these polymers (P-5a-P-5c) contained the different NBD moieties in the both main and side chains, the observed rates of photoisomerization of the NBD moieties in P-5a-P-5c obeyed first-order kinetics in the initial stage of the reactions (Table VII). This means that because first-order photoisomerization rate con-

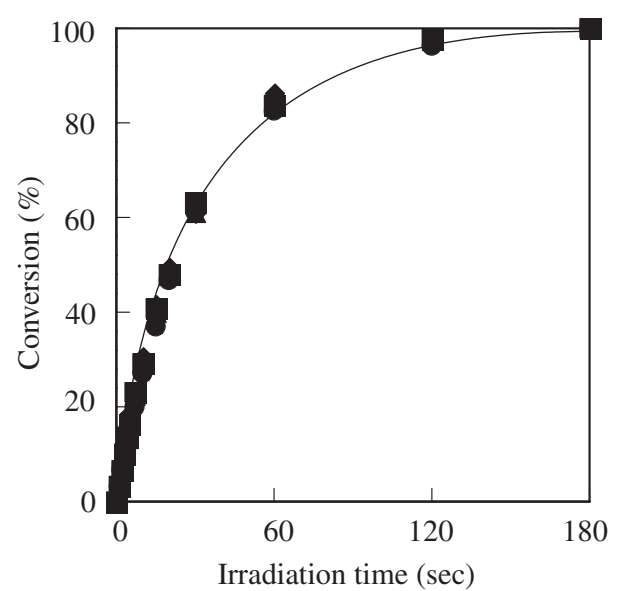

Figure 7. Time-conversion curve of photoisomerization of

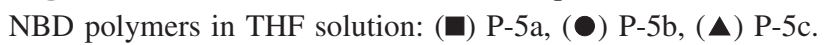

stants of NBD moieties in the main chain or side chains were expressed similar values, and the photoisomerization of P-5a-P-5c apparently follows to the first-order kinetics in the initial reaction stage.

Furthermore, the photosensitization of P-1-P-4 and $\mathrm{P}-5 \mathrm{a}-\mathrm{P}-5 \mathrm{c}$ was also investigated in the film state with BEBP as a photosensitizer. When the photochemical reaction was carried out with $10 \mathrm{~mol} \%$ of BEBP for NBD moieties, all the NBD groups of the poly(ester)s isomerized to the QC groups in a short period of time, in about only $20 \mathrm{~s}$. As summarized in Table IV, the rates of the photochemical reactions of all the polymers were remarkably enhanced (about 6-10 times) by the addition of $10 \mathrm{~mol} \%$ of BEBP in the film state.

\section{Thermal Properties of the NBD Poly(ester)s}

The $T_{\mathrm{g}}$ 's of the poly(ester)s containing the D-A NBD residues were measured with DSC at a heating rate of $10^{\circ} \mathrm{C} / \mathrm{min}$. As summarized in Table VIII, the $T_{\mathrm{g}}$ 's of P-1 and P-2 with rigid polymer skeletons were 93 and $92^{\circ} \mathrm{C}$, respectively. However, $T_{\mathrm{g}}$ 's of P-3 and $\mathrm{P}-4$ with soft polymer skeletons were lower than room temperature. The $T_{\mathrm{g}}$ 's of P-5a, P-5b, and P-5c were 104,102 , and $108^{\circ} \mathrm{C}$, respectively, which were higher than that of P-1. This means that the $T_{\mathrm{g}}$ of the resulting polymers increased with the increase of the modification of bulky NBD groups.

Next, the released thermal energies from the corresponding QC groups in the irradiated polymer films were measured by DSC. As summarized in Table VIII, the irradiated P-1, P-2, P-3, and P-4 bearing the corresponding QC groups released 76, 84, 84, and $76 \mathrm{~J} / \mathrm{g}$ of thermal energy, respectively. On the other hand, the released thermal energy in the irradiated polymers $(\mathrm{P}-5 \mathrm{a}-\mathrm{c})$ containing $\mathrm{QC}$ residues both in the both main and side chains were 153, 130, $106 \mathrm{~J} / \mathrm{g}$, respectively. These results show that P-5a$\mathrm{P}-5 \mathrm{c}$ have about 1.5 times higher stored energies in 
Table VIII. Thermal properties of NBD poly(ester) $\mathrm{s}^{\mathrm{a}}$

\begin{tabular}{cccc}
\hline \multirow{2}{*}{ Polymer } & \multirow{2}{*}{$T_{\mathrm{g}}$} & \multicolumn{2}{c}{ Stored thermal energy } \\
\cline { 3 - 4 } & $\left({ }^{\circ} \mathrm{C}\right)$ & $\mathrm{J} / \mathrm{g}$ & $\mathrm{kJ} / \mathrm{mol}$ \\
\hline P-1 & 93 & 76 & 51 \\
P-2 & 92 & 84 & 57 \\
P-3 & - & 84 & 53 \\
P-4 & - & 76 & 49 \\
P-5a & 104 & 153 & 64 \\
P-5b & 102 & 130 & 60 \\
P-5c & 108 & 106 & 49 \\
\hline
\end{tabular}

${ }^{\mathrm{a}}$ Measured by DSC.

the polymer compared with $\mathrm{P}-1$, owing to the concentration of NBD residue increased by the chemical modification.

\section{CONCLUSIONS}

From all these results, the following conclusions can be drawn:

1. The polyaddition of D-A NDGE with diacyl chlorides such as TPC and IPC was examined in the presence of TBAB as the catalyst in toluene at $100^{\circ} \mathrm{C}$ for $24 \mathrm{~h}$, and corresponding high molecular weight polyesters containing D-A NBD residue in the main chain and reactive pendant chloromethyl groups in the side chains were synthesized in good yields.

2. The poly(ester)s containing D-A NBD moieties both in the both main and side chains were synthesized by the substitution reaction of $\mathrm{P}-1$ with potassium D-A NBD carboxylates using PTC method.

3. All the synthesized NBD polymers isomerized smoothly to the corresponding QC polymers upon UV irradiation in the THF solution and in the film state.

4. The rate of the photochemical valance isomerization of the D-A NBD moieties in the polymers increased efficiently by the addition of BEBP as the photosensitizer, and all the NBD groups in the polymers isomerized to the $\mathrm{QC}$ groups in about only $20 \mathrm{~s}$.

5. The photo-irradiated polymers containing QC groups released thermal energies. Especially, $\mathrm{P}-5 \mathrm{a}-\mathrm{P}-5 \mathrm{c}$ released high thermal energies of $106-153 \mathrm{~J} / \mathrm{g}$, because the concentration of $\mathrm{D}-\mathrm{A}$ NBD residue increased by the chemical modification of $\mathrm{P}-1$.

Acknowledgment. This research work was sup- ported by High-Tech Research Project from the Ministry of Education, Culture, Sports, Science and Technology, Japan, which is gratefully acknowledged.

\section{REFERENCES}

1. R. R. Hautala, J. Little, and E. Sweet, Sol. Energy Mater., 19, 503 (1977).

2. R. B. King and E. M. Sweet, J. Org. Chem., 44, 385 (1979).

3. R. R. Hautala, R. B. King, and C. Kutal, "Solar Energy; Chemical Conversion and Storage," Hummana Press, Totowa, NJ, 1979, p 333.

4. G. S. Hammond, N. J. Turro, and A. Fisher, J. Am. Chem. Soc., 83, 2532 (1961).

5. T. Nishikubo, T. Shimokawa, and A. Sahara, Macromolecules, 22, 8 (1989).

6. C. Hijikata and T. Nishikubo, Polym. J., 22, 551 (1990).

7. T. Nishikubo, T. Hijikata, and T. Iizawa, J. Polym. Sci., Polym. Chem. Ed., 29, 671 (1991).

8. T. Iizawa, T. Hijikata, and T. Nishikubo, Macromolecules, 25, 21 (1992).

9. T. Nishikubo, A. Kameyama, T. Nakajima, and K. Kishi, Polym. J., 24, 1165 (1992).

10. T. Nishikubo, A. Kameyama, K. Kishi, T. Kawashima, T. Fujiwara, and C. Hijikata, Macromolecules, 25, 4469 (1992).

11. K. Kishi, A. Kameyama, and T. Nishikubo, Kobunshi Ronbunshu, 50, 137 (1993).

12. T. Nishikubo, T. Kawashima, and S. Watanabe, J. Polym. Sci., Polym. Chem. Ed., 31, 1659 (1993).

13. T. Nishikubo, A. Kameyama, K. Kishi, and C. Hijikata, React. Polym., 24, 65 (1994).

14. T. Nishikubo, A. Kameyama, K. Kishi, and T. Nakajima, Macromolecules, 27, 1087 (1994).

15. T. Nishikubo, A. Kameyama, K. Kishi, and Y. Mochizuki, J. Polym. Sci., Polym. Chem. Ed., 32, 2765 (1994).

16. S. Takamura, A. Kameyama, and T. Nishikubo, Kobunshi Ronbunshu, 52, 4115 (1995).

17. I. Nishimura, A. Kameyama, T. Sakurai, and T. Nishikubo, Macromolecules, 29, 3818 (1996).

18. A. Tsubata, A. Kameyama, S. Nakamura, and T. Nishikubo, Kobunshi Ronbunshu, 54, 37 (1997).

19. I. Nishimura, A. Kameyama, and T. Nishikubo, Macromolecules, 31, 2789 (1998).

20. J. Sanpei, A. Kameyama, and T. Nishikubo, Kobunshi Ronbunshu, 55, 407 (1998).

21. Z. Yoshida, J. Photochem., 29, 27 (1985).

22. Z. Yoshida, Chem. Lett., 195 (1987).

23. A. Ikeda, A, Kameyama, T. Nishikubo, and T. Nagai, Macromolecules, 34, 2728 (2001).

24. N. Kawashima, A. Kameyama, T. Nishikubo, and T. Nagai, J. Polym. Sci., Polym. Chem. Ed., 39, 1764 (2001).

25. Y. Konno, A. Kameyama, T. Nishikubo, and T. Nagai, J. Polym. Sci., Polym. Chem. Ed., 39, 2683 (2001).

26. N. Kawashima, A. Kameyama, T. Nishikubo, and T. Nagai, React. Funct. Polym., 55, 75 (2003). 